\title{
$\mathrm{Fe}(\mathrm{IIII})$ 系新規層状含水酸化物の合成とキャラクタリゼーション
}

\author{
片元 勉 ${ }^{2}$, 橋本 英樹放, 藤井 達生放, 高田 潤的 \\ 的1 户田工業株)，７ 739-0652 大竹市明治新開 1-4. \\ 部岡山大学大学院自然科学研究科, 干 700-8530 岡山市北区津島中 3-1-1.
}

\section{Synthesis and Characterization of New Iron(III) Layered Hydroxides}

\author{
Tsutomu Katamoto ${ }^{\text {tr } 1}$, Hideki Hashimoto ${ }^{\text {is } 2}$, Tatsuo Fujii ${ }^{\text {is } 2}$ and Jun Takada ${ }^{\text {is } 2}$ \\ is 1 Toda Kogyo Corp., 1-4 Meijishinkai, Otake 739-0652, Japan. \\ ${ }^{4}{ }^{2}$ Graduate School of Natural Science and Technology, Okayama University, 3-1-1 Tsushima-naka, Kita-ku, Okayama 700-8530, Japan
}

Received December 21, 2009

\section{SYNOPSIS}

A new layered iron hydroxide was synthesized by a wet chemical technique, by which aqueous ferrous sulfate solution was gradually oxidized by using sodium carbonate at $283 \sim 333 \mathrm{~K}$. Obtained yellowish precipitates identified by X-ray powder diffraction had a similar structure to the layered double hydroxides. The observed interlayer spacing was about $d=0.74 \mathrm{~nm}$. Electron micrographs showed that the particles had plate-like morphology. Electron diffraction pattern of the plate-like particles had hexagonal symmetry, when the electron beam was aligned normal to the planes. Mössbauer spectrum suggested that all iron ions were paramagnetic $\mathrm{Fe}^{3+}$ states with large quadrupole splittings at room temperature. These results show that the obtained new layered iron hydroxide cotains only $\mathrm{Fe}(\mathrm{III})$ ion species. Water vapor adsorption curves of the sample oxidized at $291 \mathrm{~K}$ showed high adsorption value (19 wt\%) by unit weight.

\section{KEY WORDS}

Iron hydroxide, layered double hydroxide, wet chemical synthesis, TEM observation, water vapor adsorption, Mössbauer analysis

\section{1 緒 言}

ハイドロタルサイトを代表として知られる層状複水酸化物 (Layered double hydroxide, 以後 LDH と略記する) は, 一般式 $\left[\mathrm{M}^{2+}{ }_{1-x} \mathrm{M}^{3+}{ }_{x}(\mathrm{OH})_{2}\right]\left[\mathrm{A}^{n-}{ }_{x / n} \cdot y \mathrm{H}_{2} \mathrm{O}\right]$ で表される化合物である.こ こで $\mathrm{M}^{2+}, \mathrm{M}^{3+}$ は二価および三価の金属イオン, $\mathrm{A}^{n-}$ は $n$ 価のア ニオンを表す. LDHは金属水酸化物からなるカチオン層とア ニオンおよび水分子から成るアニオン層が交互に積層した層 状構造を有しており, $\mathrm{M}^{3+}$ イオンの置換量 $x$ は最大で約 $x=0.33$ とされている ${ }^{1)}$. また, LDHの形状は層状の結晶構造に起因 して板状を呈している場合が多い. 代表的なLDHである炭酸 型ハイドロタルサイトの組成と構造モデルをFig.1に示す.カ チオン層は正に帯電しており,アニオン層はその電荷を相殺 するように負電荷を帯びている.アニオン層中のアニオンは イオン交換が可能で, アニオンの種類により経験的に安定化 序列が存在すると言われている2). 例えば, その序列は $\mathrm{CO}_{3}{ }^{2-}$ $>\mathrm{SO}_{4}{ }^{2-}>\mathrm{OH}^{-}>\mathrm{Cl}^{-}>\mathrm{NO}^{3-}$ で, $\mathrm{LDH}$ 中では $\mathrm{CO}_{3}{ }^{2-}$ イオンが最も 安定に存在できると考えられている.このようにLDHは層状
構造に起因する特異的なア二オン交換能を有することや多く の金属イオンの組み合わせが可能なことから, 様々な分野へ の応用が可能であり, 近年活発に研究されている. 例えば, LDH の具体的な用途としては, ハロゲン含有樹脂用安定剂, 農業用フィルム用保温剂, 廃水処理剤, 医薬品等多数ある ${ }^{3)}$.

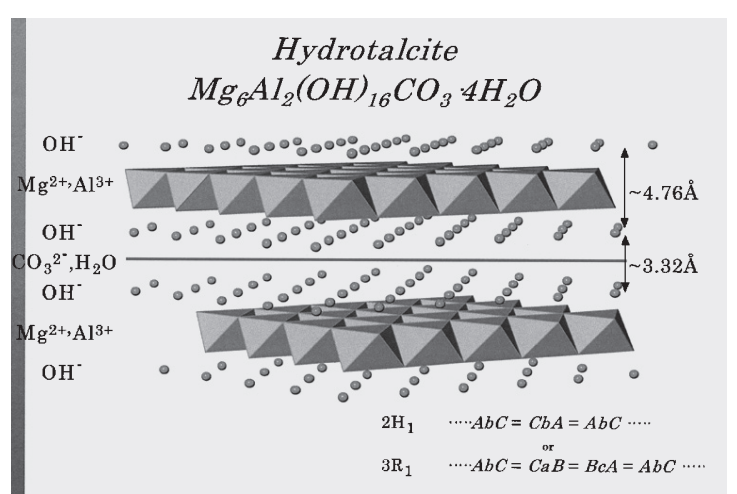

Fig.1 Structure of stoichiometric hydrotalcite. 
また, LDH の合成方法には, 主に共沈殿法, 均一沈殿法, 水 熱合成, 再構築法が知られている. 特にLDH微粒子を合成す る際には共沈殿法が採用されている場合が多い.

1980 年以降，鉄を含有する LDH の合成研究も増加してい る ${ }^{4-7)}$ ．例えば, $\mathrm{Mg}-\mathrm{Fe}(\mathrm{III})$ 系 $\mathrm{LDH}, \mathrm{Ni}(\mathrm{II})-\mathrm{Fe}(\mathrm{III})$ 系 $\mathrm{LDH}$, $\mathrm{Fe}(\mathrm{II})-\mathrm{Fe}(\mathrm{III})$ 系LDHなどが合成されている。 それらの合成方 法は共沈殿法-7)が主体であるが, 湿式空気酸化法による研究 もH. Drissi $ら^{8)}$ によって報告されている．また，金属鉄の腐 食機構の解明のために $\mathrm{Fe}(\mathrm{II})-\mathrm{Fe}(\mathrm{III})$ 系LDHであるグリーンラ スト (Green Rust: 略称 GR) のメスバウアースペクトル解析等 が行われた ${ }^{8)}$.ここで $\mathrm{GR}$ とは，水酸化第一鉄 $\mathrm{Fe}(\mathrm{OH})_{2}$ を酸化 する際に酸化反応条件により生成する中間体である9".この 様に,これまでの鉄のみから構成されるLDHの研究では, 結 晶学的に安定な $\mathrm{Fe}(\mathrm{II})-\mathrm{Fe}(\mathrm{III})$ 系 LDH(GR) を対象としている. 近年, Legrand らはアニオンを $\mathrm{CO}_{3}{ }^{2-}$ とする炭酸型 $\mathrm{GR}$ から, その結晶母体であるカチオン層中の $\mathrm{Fe}(\mathrm{II})$ イオンをゆっくり と $\mathrm{Fe}(\mathrm{III})$ に酸化することで, $\mathrm{Fe}(\mathrm{II})$ イオンを全く含まない $\mathrm{Fe}(\mathrm{III})$ イオンのみから成る $\mathrm{Fe}$ (III) 系LDHとして GR-Fe(III)の 合成を試みた。 その結果，LDHに類似の層状を持った新たな オキシ水酸化炭酸鉄 (III) 相が存在することを報告し, exGRc $-\mathrm{Fe}(\mathrm{III})$ と命名している ${ }^{10)}$. しかし, exGRc-Fe(III)の完全な単 相合成には成功していない，その主な理由は，この $\mathrm{GR}-\mathrm{Fe}(\mathrm{III})$ の生成がゲーサイト $(\alpha-\mathrm{FeOOH})$ 等のオキシ水酸化鉄(III)相の 生成と競争関係にあるためである.

本研究の目的は, 次の三つである. 第 1 に, これまで合成 が成功していない $\mathrm{Fe}(\mathrm{III})$ のみで構成される Fe(III) 系 LDH の 合成方法の確立である. 第2に得られた Fe(III) 系LDHの形態 的，結晶構造的な特徵を明らかにすることである。第 3 に得 られた Fe(III)系LDHの熱的安定性を検討することである. 具 体的には, 湿式空気酸化反応法におけるLDHの生成之湿式分 解反応の制御法を応用して, 酸化雾囲気下でも取り扱いが容 易な $\mathrm{Fe}(\mathrm{III})$ から成る新規層状含水酸化鉄である $\mathrm{Fe}(\mathrm{III})$ 系 LDH を合成するとともに，その生成領域を明らかにする，そのた めに, LDHの層間では炭酸イオンが最も安定であること,お よび含水酸化鉄粒子との相互作用が強いことを考慮して, 炭 酸イオン共存下で $\mathrm{Fe}(\mathrm{II})$ イオンを急速に湿式空気酸化するこ とにより, 炭酸型の $\mathrm{Fe}(\mathrm{III})$ 系 LDH微粒子の合成を試みる. 次 に, 得られた $\mathrm{Fe}$ (III) 系 LDH の形状, 粒子サイズ, 結晶構造, 微細構造, 組成, 化学状態を透過型電子顕微鏡 (TEM), X 線 回折 (XRD), メスバウアー分光等の分析方法によって評価し た. 加えて, ここで得られた $\mathrm{Fe}(\mathrm{III})$ 系 $\mathrm{LDH}$ は，従来の鉄系 LDH の合成方法と異なる合成方法で作成された新規な LDH であるため, 空気雾囲気中での熱的安定性を検討した。

\section{2 実験方法}

実験に使用した反応槽の模式図をFig.2に示す. 湿式空気反 応槽は底部に空気導入ノズルを有するコーン状のステンレス 製で,ヒーター, 温度センサー, $\mathrm{pH}$ 電極, ORP電極を備えて いて，効率よく微細な気泡を発生できる構造を有している。
Fe $\mathrm{LDH}$ (炭酸型)の合成は, $\mathrm{Na}_{2} \mathrm{CO}_{3}$ (99\% 米山薬品工業) 1.44 $\sim 3.6 \mathrm{~mol}$ を蒸留水に溶解して, 所定温度の溶液 $3.0 \mathrm{dm}^{3}$ に調製 し, 内容積 $10 \mathrm{dm}^{3}$ 空気酸化反応槽に投入した (A 液). 次に, $\mathrm{FeSO}_{4} \cdot 7 \mathrm{H}_{2} \mathrm{O}$ ( $99 \%$ 以上 米山薬品工業) $1.2 \mathrm{~mol}$ を蒸留水溶 解して, $\mathrm{H}_{2} \mathrm{SO}_{4}$ (99\% 米山薬品工業) $2 \mathrm{ml}$ 加え $\mathrm{pH} 2.3$ の所 定温度の溶液 $1.0 \mathrm{dm}^{3}$ に調整した ( $\mathrm{B}$ 液). 空気反応槽内の $\mathrm{A}$ 液 に B 液を添加して, 所定温度 $(283 \sim 333 \mathrm{~K})$ と所定空気流量 (5 $\sim 25 \mathrm{dm}^{3} / \mathrm{min}$ ) で空気酸化を行った. 空気酸化反応の終点は, 酸化還元電位の変化がなくなつた点としたが，これに加えて 赤血塩チェック法 (希硫酸とフェリシアン化カリウムの混合 溶液を接触させ色調を観察する方法)により鉄(II)イオンが消 失していることを確認した．また反応途中の中間生成物を同 定するために, 反応途中のサスペンションの一部を抜き取り, ポリ塩化ビニリデンフィルムで酸化を防止しながら脱酸素蒸 留水で洗浄し, 真空凍結乾燥処理を行った. 空気酸化反応後 の黄褐色サスペンションは, ろ過水洗した後に, 凍結乾燥に よって粉末試料を得た.

得られた試料の評価には，X線回折装置(XRD, RINT2500, リガク), 透過型電子顕微鏡(TEM, JEM-1200EXII, JEM-2100F, JEOL), 炭素硫黄計(EMIA-820, HORIBA), 発光プラズマ分光 分析 (ICP, iCAP6300DUO，サーモフィシャー), BET 比表面

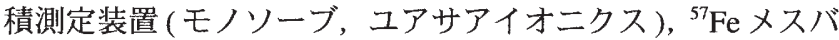
ウアー分光測定機 (トポロジックシステムズ), 水蒸気吸着量 測定装置 (ベルソープ aqua ${ }^{3}$ ，日本ベル)を用いた．また，乾 燥粉末の熱的特性を調べるために, 乾燥試料 $2.0 \mathrm{~g}$ をアルミナ 製ルツボに入れ，空気䨌囲気下で 2 時間，所定の温度 (393〜 $723 \mathrm{~K})$ でマッフル炉中で加熱した.

\section{3 実験結果および考察}

$3.1 \mathrm{Fe}(\mathrm{III})$ 系 LDH $の$ 合成

$\mathrm{Fe}$ (III) 系 LDH を合成するために鉄濃度 $0.3 \mathrm{M}$, 初期炭酸ナ トリウム濃度 $0.9 \mathrm{M}$, 反応温度 $283 \mathrm{~K}$, 空気流量 $25 \mathrm{dm}^{3} / \mathrm{min}$ の 反応条件で空気酸化反応を行い, 反応時間による生成相の変 化を追跡した. 反応途中のサスペンションを反応槽からサン プリングし，酸化や熟成を防止して凍結乾燥を行い，XRD測 定により生成物の評価を行った. 反応時間は $0,20,40,80,120$, $240 \mathrm{~min}$ し, この一連のサンプルを A シリーズとした(A-S0

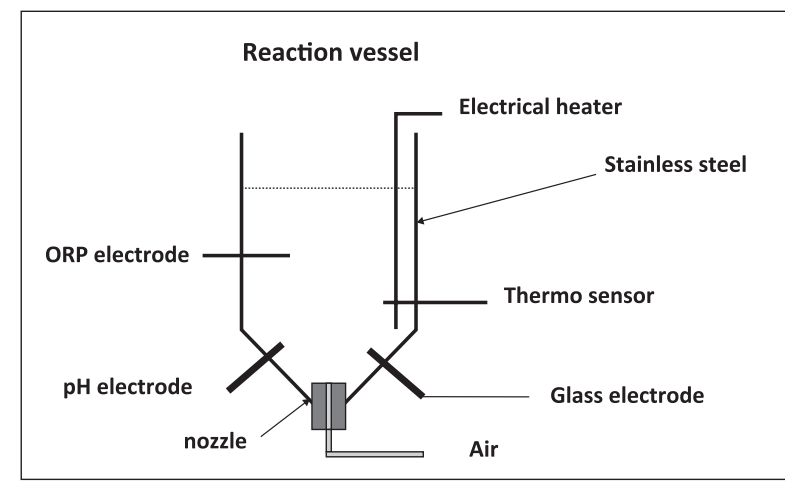

Fig.2 Illustration of the reaction vessel. 
〜 A-S5). なお， 反応途中のサスペンション $(\mathrm{A}-\mathrm{S} 0 \sim \mathrm{A}-\mathrm{S} 3)$ は 空気酸化が極めて早く進行するために, XRD 測定は $2 \theta=5.0$ $\sim 30.0$ 度付近のみの測定とした. Fig.3に空気酸化反応が終了 した A-S5の XRDパターンを示す. XRDパターンから, 反応 時間 $0 \mathrm{~min}$ の A-SO は $\mathrm{FeCO}_{3}$ が生成していた。一方, 反応時間 $20 \mathrm{~min}$ 以上のサンプル A-S1 A-S5 ではLDHの層間隔に相当 する $\mathrm{d}_{003}=0.74 \sim 0.75 \mathrm{~nm}$ のピークが確認され, $\mathrm{LDH}$ と同様に 層状構造を有していることが明らかとなった. しかし，酸化 の進行とともに高次の反射である $\mathrm{d}_{006}$ に対応する回折線の強 度は急速に低下し，A-S4 および A-S5 では完全に消失した。 すなわち，LDH 結晶の長距離秩序性は A-S4 および A-S5 で はほぼ失われており，箃密な意味での Fe(III) 系 LDH の合成 は困難であった。

ところで, LDHの層構造に着目し, A-S1 A-S5 の $\mathrm{d}_{003}$ 值を 比較すると，A-S1 およびA-S2 はそれぞれ $\mathrm{d}_{003}=0.753,0.752$ $\mathrm{nm}$ であるのに対し，A-S3 $\mathrm{d}_{003}=0.744 \mathrm{~nm}$ およびA-S4, A-S5 は $\mathrm{d}_{003}=0.740 \mathrm{~nm}$ と僅かに短くなっていることが確認された. この酸化にともなうLDHの首間隔の減少はLegrandらの報告 とも一致している ${ }^{10)}$. 彼らは炭酸型 GR が酸化され exGRc$\mathrm{Fe}(\mathrm{III})$ に変化すると層間隔が $\mathrm{d}_{003}=0.758 \mathrm{~nm}$ から $0.734 \mathrm{~nm}$ へ 減少すると報告している. また Fig.3の A-S5 の XRD パターン は, Legrandらが報告したexGRc-Fe(III)のXRDパターンと全

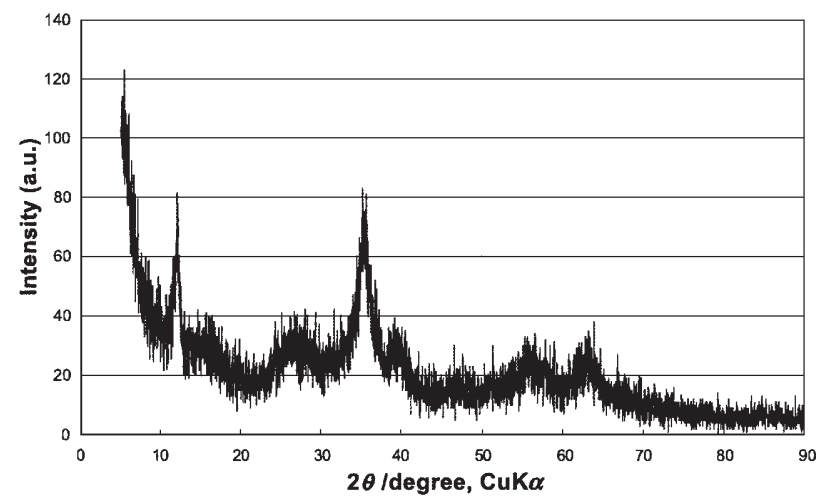

Fig.3 XRD pattern of Fe(III) pseudoLDH (sample A-S5).
角度範囲でよく類似しており,同様の $\mathrm{Fe}(\mathrm{III})$ 系層状含水酸化物 が生成している可能性が高い。しかも, Fig.3では, $\alpha$ - FeOOH などに帰属される不純物ピークが認められないことから, 本 研究で初めて LDHに類似の層状構造をもつ $\mathrm{Fe}(\mathrm{III})$ 系含水酸 化物の単相合成に成功したといえる。しかし, exGRc-Fe(III) と本研究で合成した $\mathrm{Fe}(\mathrm{III})$ 系層状含水酸化物の XRD パター ンは, その合成方法において出発原料や反応条件が違うため か, $\mathrm{d}$ 值やピーク強度比などの点で微妙に異なっている.よっ て本研究で合成した $\mathrm{Fe}(\mathrm{III})$ 系首状含水酸化物のことを, 以 後, LDH 類似 $\mathrm{Fe}$ (III) 化合物 (Fe(III) pseudo LDH) と記述する ことにする.

ここで, 反応中の酸化還元電位の変化およびサスペンショ ンの赤血塩チェック法の結果を述べる. 反応中の酸化還元電 位は, 酸化反応開始後 $20 \mathrm{~min}$ で最大になり, その後急激に低 下し, 反応開始後 $120 \min$ から変化は極めて緩やかになり, 反 応開始後 $180 \mathrm{~min}$ でほとんど変化しなくなった。この酸化還 元電位の測定結果より, サンプル $\mathrm{A}$ の湿式空気酸化反応の場 合, 酸化反応開始後 $120 \mathrm{~min}$ で $\mathrm{Fe}(\mathrm{II})$ イオンの酸化反応はほぼ 終了していることが明らかとなった.さらに，赤血塩チェッ ク法により, 酸化反応開始後 $120 \min$ のサスペンションには $\mathrm{Fe}(\mathrm{II})$ が存在していないことを確認した. また, Aシリーズサン プルの $\mathrm{Fe}(\mathrm{II})$ の存在の有無を赤血塩チェック法で評価したと ころ, A-S0〜 A-S2については Fe(II)が検出されたが，A-S3 〜 A-S5については $\mathrm{Fe}$ (II) が検出されなかった.

以上のXRD測定, 酸化還元電位の測定および赤血塩チェッ ク法の結果から，A-S0 A-S2 は通常の Fe(II)Fe(III) 系 LDH であり, A-S3はd $=0.744 \mathrm{~nm}$ で層状構造が歪んだ $\mathrm{Fe}$ (II)- $\mathrm{Fe}$ (III) 系LDHであり,A-S4〜A-S5 はFe(II)が完全に酸化されたLDH 類似 $\mathrm{Fe}$ (III) 化合物であると考えられる。

Fig.4に, 層状構造を有する反応開始後 $20 \mathrm{~min}$ (A-S1) と反応 開始後 $240 \mathrm{~min}(\mathrm{~A}-\mathrm{S} 5)$ にサンプリングした粉末のTEM写真を 示す. $\mathrm{Fe}(\mathrm{II})-\mathrm{Fe}(\mathrm{III})$ 系LDHであるサンプル A-S1 は粒子サイズ $50 \sim 200 \mathrm{~nm}$ の六角板状粒子であるのに対し，LDH類似Fe(III) 化合物である A-S5 は粒子サイズ $50 \sim 200 \mathrm{~nm}$ のエッジがやや

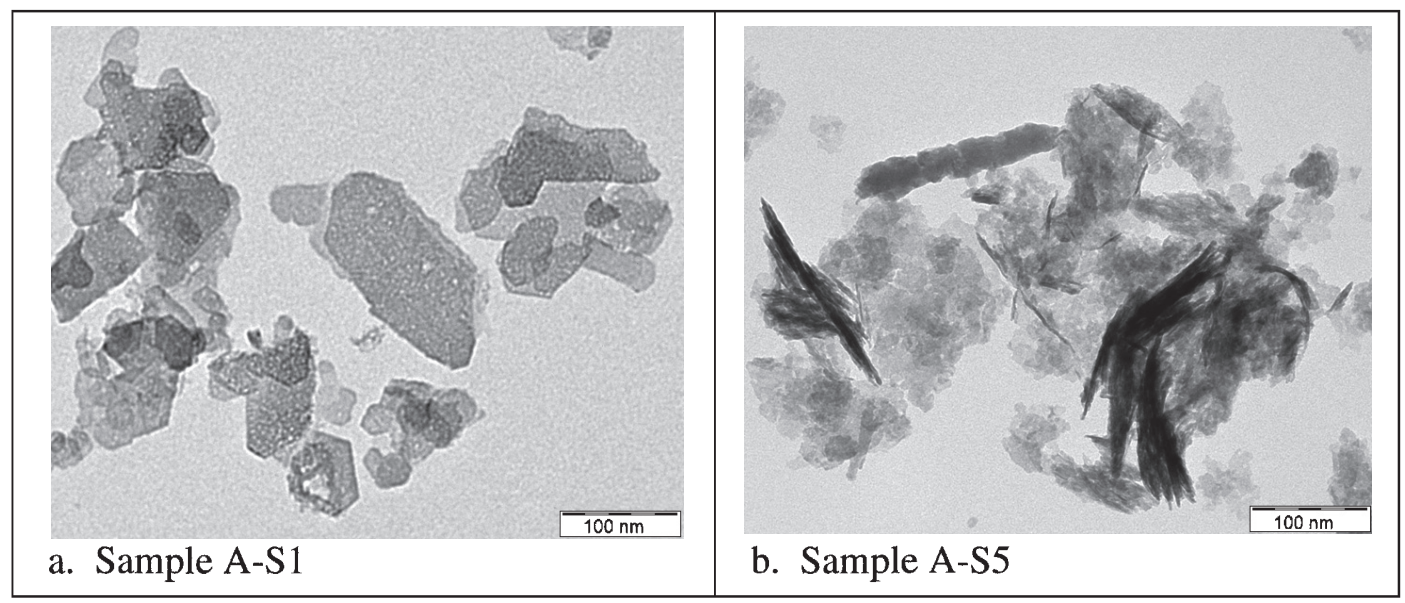

Fig.4 TEM images of $\mathrm{Fe}(\mathrm{II}) / \mathrm{Fe}(\mathrm{III}) \mathrm{LDH}$ and $\mathrm{Fe}(\mathrm{III})$ pseudoLDH with different oxidation time. a) sample A-S1 (20 min), and b) A-S5 (240 min). 
不明瞭な板状粒子であることを見出した. A-S1〜A-S5 はいず れも板状粒子であるが, LDH類似 $\mathrm{Fe}$ (III) 化合物 (A-S5)になる とエッジがやや不明膫な板状粒子が生成することが明らかと なった。

また, 粉末の組成分析の結果, 粉末中の炭素(C)量とサルファー (S) 量が酸化反応と共に変化することがわかった. 粉末中のC 量は反応開始後 $20 \mathrm{~min}(\mathrm{~A}-\mathrm{S} 1)$ で最大值 $0.97 \mathrm{wt} \%$ に達し, その 後反応時間の経過とともに減少した. 一方, 粉末中の $\mathrm{S}$ 量は 空気酸化反応開始後 $20 \mathrm{~min}$ のサンプル (A-S1) で最大值 0.50 $\mathrm{wt} \%$ に達し, その後反応時間の経過とともに減少し, 反応開 始後 120 min のサンプル (A-S4) からは検出されなくなった. つまり, A-S4およびA-S5 の LDH 類似 $\mathrm{Fe}$ (III) 化合物は $\mathrm{SO}_{4}{ }^{2-}$ イオンを含んでおらず, exGRc-Fe(III) と同様に炭酸型である ことが明らかとなった. 以上の結果をTable 1にまとめ示した. $3.2 \mathrm{LDH}$ 類似 $\mathrm{Fe}(\mathrm{III})$ 化合物の生成領域の確認

$\mathrm{Na}_{2} \mathrm{CO}_{3}$ 濃度と反応温度によって LDH 類似 $\mathrm{Fe}(\mathrm{III})$ 化合物の 生成領域がごのように変化するかを調べるために, Fe濃度を $0.3 \mathrm{M}$, 空気流量を $25 \mathrm{dm}^{3} / \mathrm{min}$ および反応時間を $240 \mathrm{~min}$ に固 定して, $\mathrm{Na}_{2} \mathrm{CO}_{3}$ 濃度と反応温度を変化させた. Fig. 5 に, 得 られた生成物のXRD測定, 赤血塩チェック法およびTEM観 察から判明した結晶相の生成領域図を示す.ここで, LDH類 似 $\mathrm{Fe}$ (III) 化合物生成の判断基準は, XRD 測定で $\mathrm{d}=0.740 \mathrm{~nm}$ のピークが確認されること, $\mathrm{Fe}(\mathrm{II})$ が検出されないことおよ び板状粒子であることとした, 反応温度 $303 \mathrm{~K}$ 以下であり, か つ $\mathrm{Fe}(\mathrm{II})$ イオンに対する $\mathrm{Na}_{2} \mathrm{CO}_{3}$ のモル比率が $200 \mathrm{~mol} \%$ 以上 の反応条件では, LDH 類似 $\mathrm{Fe}$ (III) 化合物 (図中) が生成し た.これに対して, 反応温度 $313 \mathrm{~K}$ 以上の場合や $\mathrm{Fe}$ (II) イオ ンに対する炭酸ナトリウムのモル比率が $150 \mathrm{~mol} \%$ 以下の場合 には, 針状ゲーサイト $(\alpha \mathrm{FeOOH})$ (図中O)が生成した. 次に, 空気流量と反応温度によって LDH 類似 $\mathrm{Fe}$ (III) 化合物の生成 領域がごのように変化するかを調べるために, Fe(II) イオン に対する $\mathrm{Na}_{2} \mathrm{CO}_{3}$ のモル比率を $300 \mathrm{~mol} \%$ ，反応時間を $240 \mathrm{~min}$ に固定して, 空気流量と反応温度を変化させた. Fig.6に各結

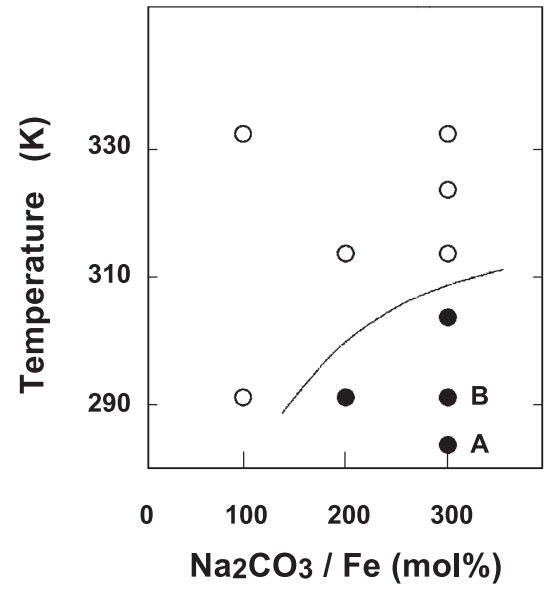

Fig.5 Formation range of $\mathrm{Fe}$ (III) pseudoLDH as a function of the oxidation temperature and the $\mathrm{Na}_{2} \mathrm{CO}_{3} / \mathrm{Fe}$ mixing ratio. and $\bigcirc$ indicate the (III) pseudoLDH phase and goethite phase, respectively.

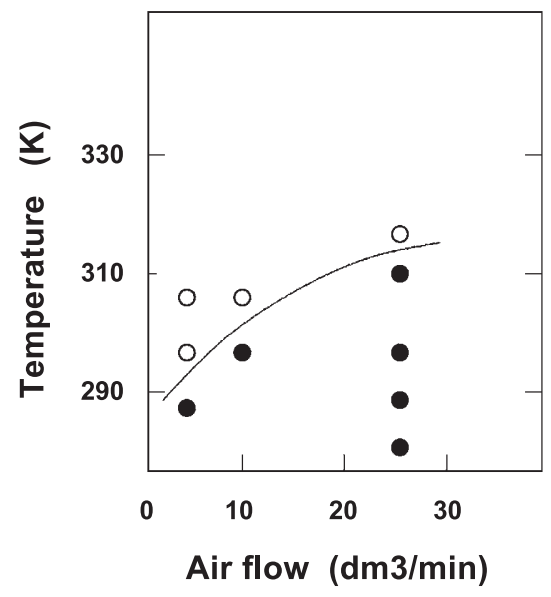

Fig.6 Formation range of $\mathrm{Fe}$ (III) pseudoLDH as a function of the oxidation temperature and the air flow rate. $\bigcirc$ and $\bigcirc$ indicate the Fe(III) pseudoLDH phase and goethite phase, respectively.

Table 1 Characterization of precursors in suspension (sample A series) with varius oxidation time.

\begin{tabular}{|l|l|l|l|l|l|l|l|c|}
\hline Sample & $\begin{array}{l}\text { Oxidation } \\
\text { time (min) }\end{array}$ & XRD phase & $\begin{array}{l}\mathrm{d}(\mathrm{nm}) \\
\mathrm{LDH}(003)\end{array}$ & Colour & $\begin{array}{l}\text { Paticle } \\
\text { shape }\end{array}$ & $\mathrm{Fe}^{2+}$ & $\begin{array}{l}\text { Carbon } \\
(\mathrm{wt} \%)\end{array}$ & $\begin{array}{l}\text { Sulfur } \\
(\mathrm{wt} \%)\end{array}$ \\
\hline A-S0 & $\mathbf{0}$ & $\mathrm{FeCO}_{3}$ & - & $\begin{array}{l}\text { light } \\
\text { blue }\end{array}$ & glanular & $\mathrm{D}$ & - & - \\
\hline A-S1 & 20 & LDH & $\mathbf{0 . 7 5 3}$ & $\begin{array}{l}\text { dark } \\
\text { green }\end{array}$ & plate-like & $\mathrm{D}$ & $\mathbf{0 . 9 7}$ & 0.5 \\
\hline A-S2 & 40 & LDH & $\mathbf{0 . 7 5 2}$ & $\begin{array}{l}\text { dark } \\
\text { green }\end{array}$ & plate-like & $\mathrm{D}$ & $\mathbf{0 . 9 5}$ & 0.28 \\
\hline A-S3 & $\mathbf{8 0}$ & LDH & $\mathbf{0 . 7 4 4}$ & $\begin{array}{l}\text { dark } \\
\text { brown }\end{array}$ & plate-like & D & 0.70 & 0.05 \\
\hline A-S4 & 120 & pseudoLDH & $\mathbf{0 . 7 4 0}$ & brown & plate-like & ND & 0.71 & 0 \\
\hline A-S5 & 240 & pseudoLDH & $\mathbf{0 . 7 4 0}$ & brown & plate-like & ND & 0.59 & 0 \\
\hline
\end{tabular}

D: detected ND: no detected 
晶相の生成領域図を示す. 空気流量の減少に伴ってLDH類似 $\mathrm{Fe}$ (III)化合物の生成領域が低温側にシフトすることがわかっ た。すなわち Fig.5 および Fig.6より，反応温度が 303K 以下 で, 反応溶液中の $\mathrm{Na}_{2} \mathrm{CO}_{3}$ の濃度が高く, かつ $\mathrm{Fe}(\mathrm{II})$ イオンの 酸化速度が速い大空気流量の条件で, LDH類似 $\mathrm{Fe}$ (III) 化合物 が生成することが明らかとなった。

Table 2 に, Fig.5に示したサンプル A およびB の粉体特性 を示す. LDH類似 $\mathrm{Fe}(\mathrm{III})$ 化合物が生成したサンプル Aおよび

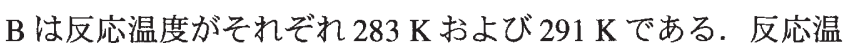
度が低いほどXRDパターンの $\mathrm{d}=0.740 \mathrm{~nm}$ のピークから計算 した結晶子サイズ(シェラーの式より算出)が小さくなる傾向 が認められた. 両方のサンプルには, 炭酸イオンと考えられ る炭素が含まれており, その含有量は合成温度による違いは ほとんど無く, 約 $0.6 \mathrm{wt} \%$ 程度であった. 一方, 両方のサン プル中に Sはほとんど含まれておらずその含有量は $0.01 \mathrm{wt} \%$ 未満であった. また, サンプル中のナトリウムは原料中の炭 酸ナトリウム由来と考えられるが, 板状の粒子 $\mathrm{A}$ およびBの ナトリウム含有量は $0.02 \mathrm{wt} \%$ 以下であった.これらの結果か ら, サンプルの構造中に存在するカチオンは $\mathrm{Fe}(\mathrm{III})$ イオンの みで, アニオンは $\mathrm{CO}_{3}{ }^{2-}$ のみであることが明らかとなった.

次節 3.3 では, Fig.5の LDH 類似 $\mathrm{Fe}(\mathrm{III})$ 化合物の生成領域 図の中心位置に当たるサンプル $\mathrm{B}$ について，キャラクタリ ゼーションを行った.

$3.3 \mathrm{LDH}$ 類似 $\mathrm{Fe}(\mathrm{III})$ 化合物のキャラクタリゼーション 3.3.1 微構造および結晶構造

合成した LDH 類似 $\mathrm{Fe}(\mathrm{III})$ 化合物の微構造を明らかにする ためにTEM 観察および電子線回折 (ED) 解析を行った. Fig.7 にサンプル B の TEM 写真を示す. Fig.7a および Fig.7bから, このサンプルは粒子径 $50 \sim 200 \mathrm{~nm}$, 厚さ $25 \mathrm{~nm}$ の板状粒子で あることがわかった. またFig.7aの右下に挿入した拡大像から， 粒子内に約 $3 \mathrm{~nm}$ の空孔が存在していることが明らかとなっ た.このサンプルは, ハイドロタルサイト $\left(\mathrm{Mg}_{6} \mathrm{Al}_{2}(\mathrm{OH})_{16} \mathrm{CO}_{3}\right.$ $\cdot 4 \mathrm{H}_{2} \mathrm{O}$ ) と同じ結晶構造(菱面体晶系, $\mathrm{R} 3 \mathrm{~m}$ ) であると考えると, Fig.7a の挿入図の電子線回折図 (ED) は, 菱面体晶の [111] 入 射パターンとして指数付けることができる.

Table 2 Characterization of Fe(III) pseudoLDH (sample A and B).

\begin{tabular}{|c|c|c|}
\hline Characterization/Sample & SampleA & SampleB \\
\hline Oxidation temperature (K) & 283 & 291 \\
\hline Crystal structure & pseudoLDH & pseudoLDH \\
\hline Particle shape & plate-like & plate-like \\
\hline Specific surface area $\left(\mathrm{m}^{2} / \mathrm{g}\right)$ & 186 & 89 \\
\hline Particle size (nm) & $50 \sim 200$ & $100 \sim 200$ \\
\hline Crystallite size (nm) & 22 & 25 \\
\hline$(w t \%)$ & 0.59 & 0.57 \\
\hline$(w t \%)$ & $\mathbf{0}$ & $\mathbf{0}$ \\
\hline$(w t \%)$ & 0.02 & 0.01 \\
\hline
\end{tabular}

以上の TEM 観察, ED 回折およびXRD測定の結果から, 本 研究で合成した LDH 類似 $\mathrm{Fe}(\mathrm{III})$ 化合物はハイドロタルサイ 卜之同样の層状構造を有する板状単結晶粒子であり, 結晶内 に直径 2 3 nm の細孔が存在することが明らかとなった.

3.3.2 LDH 類似 $\mathrm{Fe}(\mathrm{III})$ 化合物のメスバウアースペクトル解析

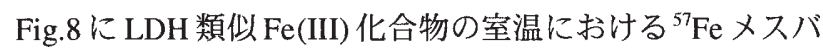
ウアースペクトルを示す.このスペクトルから LDH 類似

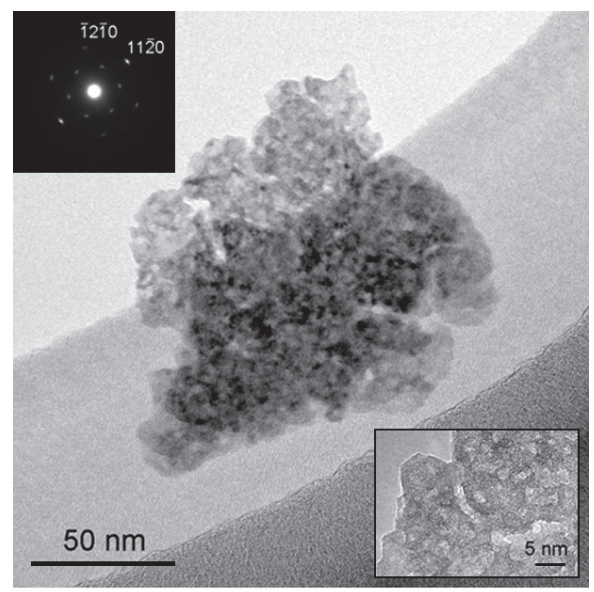

(a)

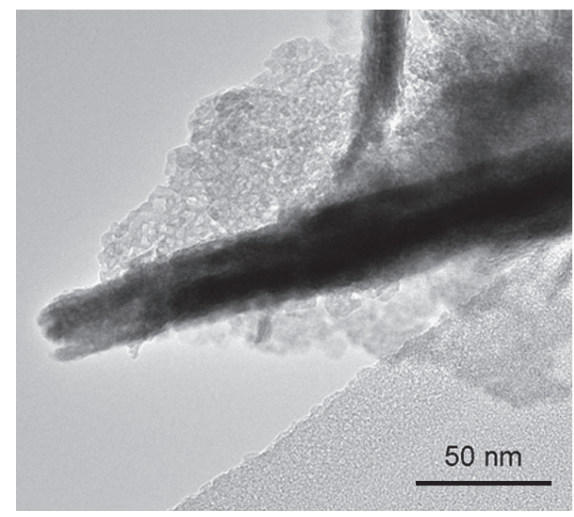

(b)

Fig.7 a) Selected area TEM image and electron diffraction patterns of Fe(III) pseudoLDH (sample B). b) Cross section TEM image of $\mathrm{Fe}$ (III) pseudoLDH (sample B).

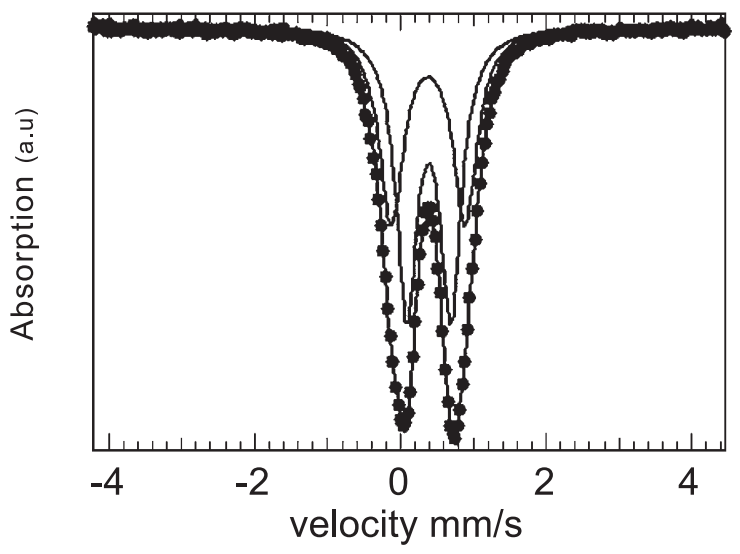

Fig.8 Room temperature Mössbauer spectrum of Fe(III) pseudoLDH (sample B). 
$\mathrm{Fe}(\mathrm{III})$ 化合物は室温で磁気的なオーダーリングを示さないこ とがわかった。 また，このスペクトルの吸収幅はややブロー ドなダブレットと考えられるので，2組のダブレットを仮定 してアイソマーシフト $0.39 \mathrm{~mm} / \mathrm{s}$, 核四重極分裂 $0.60 \mathrm{~mm} / \mathrm{s}$ の ピーク 1 (面積 $55 \%$ ) とアイソマーシフト $0.38 \mathrm{~mm} / \mathrm{s}$, 核四重 極分裂 $1.01 \mathrm{~mm} / \mathrm{s}$ のピーク 2 (面積 $45 \%$ ) に分離した. アイソ マーシフトの値より LDH 類似 $\mathrm{Fe}$ 化合物を構成する鉄イオン の価数は全て Fe(III) であることが再確認できる.さらに，核 四重極分裂值がゲーサイトの值 ${ }^{11)}$ のならず低結晶性の含水 酸化鉄として知られる 2-line ferrihydriteの值 ${ }^{12)}$ よりも大きい ことから, 結晶中の $\mathrm{Fe}(\mathrm{III})$ イオンを取り巻く酸素イオンや水 酸イオンの配置は，一般的に知られた含水酸化鉄を構成して いる $\mathrm{Fe}(\mathrm{III})$ イオンのそれよりも歪んでいると考えられる.

\subsection{3 加熱処理による特性変化}

サンプル B の LDH 類似 $\mathrm{Fe}(\mathrm{III})$ 化合物について, 空気中で 393 723 K の範囲で加熱処理した場合の粉体特性を Table 3 に示す. また Fig.9に, 加熱前と $393 \mathrm{~K}$ で $120 \mathrm{~min}$ 加熱処理し た後の LDH 類似 $\mathrm{Fe}(\mathrm{III})$ 化合物についての代表的な XRD パ ターンを示す. $393 \mathrm{~K}$ 以上で加熱すると，低角度域に出現す る $\mathrm{d}=0.74 \mathrm{~nm}$ のピークが観察されなくなることから, LDHの 層状構造に起因する周期構造が加熱処理により破壊されるこ とがわかった. 一方, 高角度側のパターンについては, 加熱 温度 $393 \mathrm{~K}$ では加熱していないものと比較して顕著な変化は

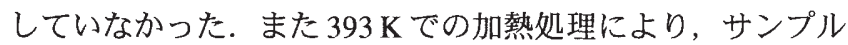
B の板状粒子は熱分解して, 粒子内に細孔が生じ，加熱前の 比表面積 $89 \mathrm{~m}^{2} / \mathrm{g}$ 品ら加熱処理後 $255 \mathrm{~m}^{2} / \mathrm{g}$ に大きく増大するこ とがわかった. さらに, サンプル $\mathrm{B}$ の熱分解温度はゲーサイ 卜の熱分解温度 $503 \sim 533 \mathrm{~K}^{13,14)}$ と比較して著しく低温である ことが明らかとなった。

以上の結果から, $\mathrm{LDH}$ 類似 $\mathrm{Fe}(\mathrm{III})$ 化合物は簡単な低温加熱 処理によって, その層状構造は容易に失うものの比表面積を 増大させることが可能であり，そのもの自体は活性が高い物 質であることが明らかとなった。

\subsubsection{LDH 類似 $\mathrm{Fe}(\mathrm{III})$ 化合物の水蒸気吸着特性}

Fig.10に, 室温におけるサンプル B の LDH 類似Fe(III) 化合

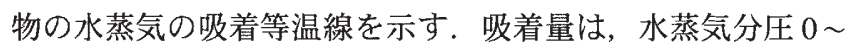
$80 \%$ の領域で水蒸気分圧と共に直線的にゆるやかに增加し, 80 95\%の領域において急激に増加した. また, 水蒸気分圧 が高い領域では吸着等温線はヒステリシスを示した.この吸
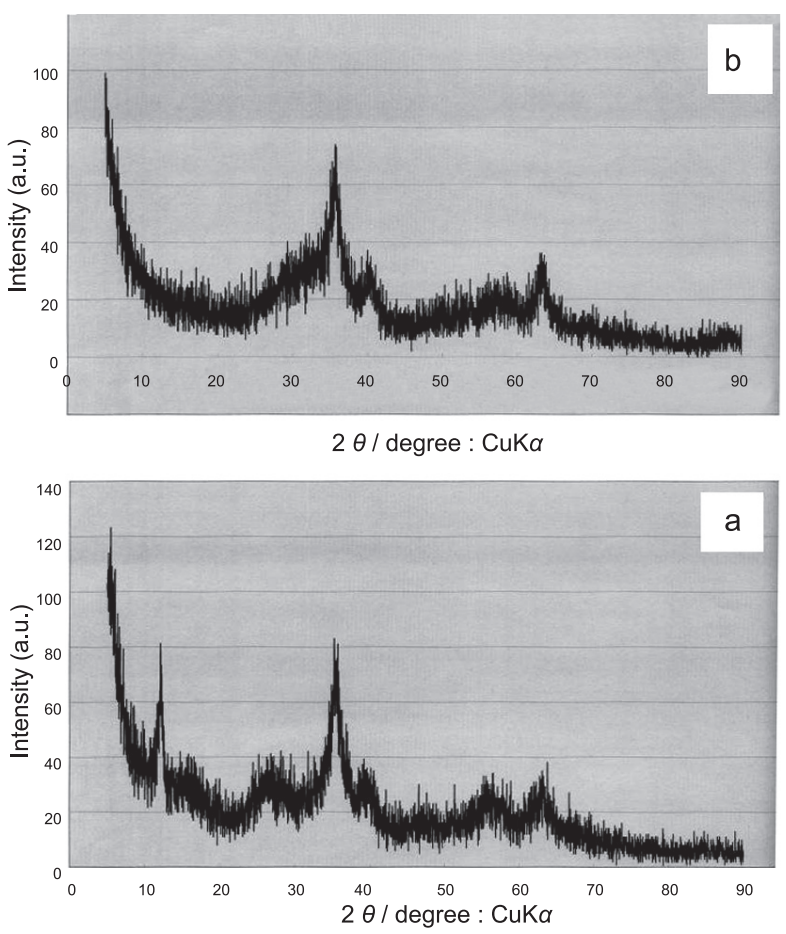

Fig.9 XRD patterns of Fe(III) pseudoLDH (sample B), a) before and $\mathrm{b}$ ) after the heat treatment at $393 \mathrm{~K}$ for 2 hours.

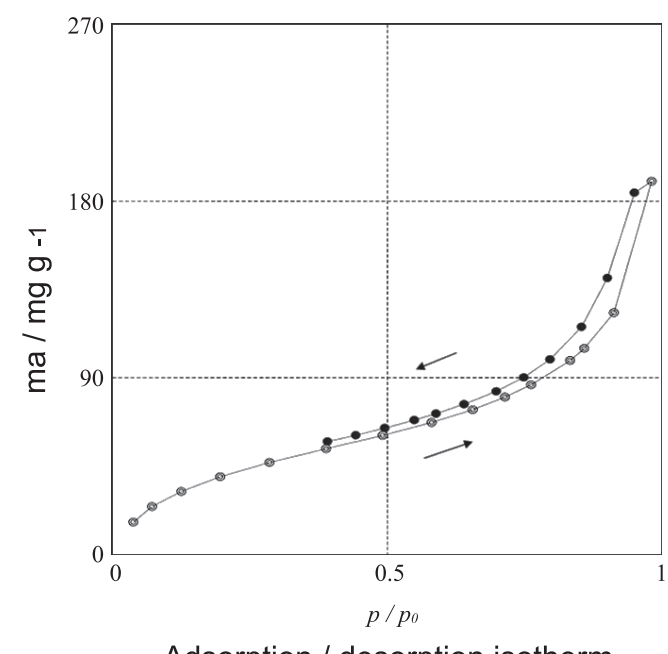

Adsorption / desorption isotherm

Fig.10 Water vapor adsorption / desorption curves at $298 \mathrm{~K}$ for $\mathrm{Fe}(\mathrm{III})$ pseudoLDH (sample B).

Table 3 Characterization of Fe(III) pseudoLDH (sample B) at various heat treatment temperatures.

\begin{tabular}{|l|l|l|l|l|l|}
\hline Heat treatment temperature (K) & 333 & 393 & 423 & 573 & 723 \\
\hline XRD phase & pseudoLDH & $A^{*}$ & $\alpha \mathrm{Fe}_{2} \mathrm{O}_{3}$ & $\alpha \mathrm{Fe}_{2} \mathrm{O}_{3}$ & $\alpha \mathrm{Fe}_{2} \mathrm{O}_{3}$ \\
\hline Specific surface area $\left(\mathrm{m}^{2} / \mathrm{g}\right)$ & 89 & 255 & 215 & 140 & 40.3 \\
\hline Weight loss $(\mathbf{w t} \%)$ & 0 & 11.2 & 14.6 & 22.3 & 23.5 \\
\hline Carbon (wt \%) & 0.59 & 0.62 & 0.31 & 0.09 & 0.06 \\
\hline Sulfur (wt\%) & 0 & 0 & 0 & 0 & 0 \\
\hline
\end{tabular}

A*: broard peaks 
着等温線はシリカのB型とID型15)の中間であることがわかっ た.この結果からサンプル中にはマイクロポア ( $2 \mathrm{~nm}$ 以下)よ りもメソポア $(2 \sim 50 \mathrm{~nm})$ が多いことが明らかとなった ${ }^{16)}$.さ らに,この細孔についての結果はTEM観察結果と良い一致を 示している. LDH類似 $\mathrm{Fe}(\mathrm{III})$ 化合物の単位重量当たりの吸着 量は, 飽和水蒸気圧の領域で $190 \mathrm{mg} / \mathrm{g}$ (重量比で $19 \mathrm{wt} \%$ ) で あった.その値を代表的な吸着材であるID型シリカと比較す ると, ID型シリカの吸着量の約 $40 \%$ も值に達しており,一 般的な含水酸化鉄に比べて非常に高い值を示すことが明らか となった.

以上のキャラクタリゼーションの結果から, 本研究で得ら れた LDH 類似 Fe(III) 化合物粒子は, 表面に直径 $2 \sim 3 \mathrm{~nm}$ 程 度の細孔がある粒子径 50 200 nmの板状単結晶粒子で, 化学 的活性が高く他の金属イオンの含有量が低いことが明らかと なった。

$3.4 \mathrm{LDH}$ 類似 $\mathrm{Fe}(\mathrm{III})$ 化合物の生成機構に関する考察

最後に, 本研究で得られた LDH 類似 Fe(III) 化合物の生成 条件ならびにキャラクタリゼーションの結果をもとに, その 生成メカニズムについて考察する.一般的にLDHの構造が安定 して存在するのは, $\mathrm{M}^{2+}$ イオンと $\mathrm{M}^{3+}$ イオンの比が $2: 1(x=$ $0.33)$ までであり, $x=0.33$ を超えると LDH の層状構造はもは や保持できないと考えられてきた ${ }^{1)}$.これはカチオン層の正 電荷が大きくなりすぎ, 層間に挿入可能なアニオン量では層 電荷バランスが取れなくなるためである.よって $x>0.33$ ，ま してや $x=1$ では別の電荷補償モデルが存在するはずである. たとえばLegrand らは, GRから exGRc-Fe(III)への反応は可 逆的に進行していると考え, OH基からのプロトン脱離よって カチオン層の正電荷の増加が抑制できるというモデル(式(1)) を提案した ${ }^{10)}$ 。しかし，本研究の結果，合成した LDH 類似 $\mathrm{Fe}(\mathrm{III})$ 化合物は多数の細孔構造を有しており，くわえて酸化 反応後のFe(III)の配位環境は非常に歪んでいることも明らか である.すなわちLDHの酸化にはプロトン以外にも多くのイ オンが反応に関与している可能性が高い，そこで筆者らは， カチオン層に空孔を生じさせることで LDH 類似 Fe(III) 化合 物は層電荷バランスをとっているという新たなモデルを提案 したい，その構造は，層電荷バランスと炭素の組成分析の結 果より式(2)のようになると推定している.しかし，その仮説 の検証には, より正確な組成分析と結晶構造解析が必須であ り, 今後のさらなる研究の推進が必要である.

$$
\begin{aligned}
& {\left[\mathrm{Fe}_{0.667}^{2+} \mathrm{Fe}^{3+}{ }_{0.33}(\mathrm{OH})_{2}\right]\left[\mathrm{CO}_{3}{ }^{2-}{ }_{0.165} \cdot y \mathrm{H}_{2} \mathrm{O}\right]} \\
& \quad \rightarrow\left[\mathrm{Fe}^{2+} \mathrm{Fe}^{3+} \mathrm{O}_{0.33+\delta}(\mathrm{OH})_{2-\delta}\right]\left[\mathrm{COO}_{3}{ }^{2-}{ }_{0.165} \cdot y \mathrm{H}_{2} \mathrm{O}\right] \\
& {\left[\mathrm{Fe}^{2+}{ }_{0.67} \mathrm{Fe}^{3+}{ }_{0.33}(\mathrm{OH})_{2}\right]\left[\mathrm{CO}_{3}{ }_{30.16}^{2-} \cdot y \mathrm{H}_{2} \mathrm{O}\right]} \\
& \quad \rightarrow\left[\mathrm{Fe}^{2+}{ }_{0}{ }_{\mathrm{a}} \mathrm{Fe}^{3+}{ }_{1-\mathrm{a}}(\mathrm{OH})_{2}\right]\left[\mathrm{CO}_{3}{ }^{2-}(1-3 \mathrm{a}) / 2 \cdot 2 \cdot y \mathrm{H}_{2} \mathrm{O}\right] 0.2<\mathrm{a}<0.3
\end{aligned}
$$

\section{4 結言}

本論文で得られた結果を要約すると，以下の通りである. (1) $\mathrm{Fe}$ (III) 系 LDH を合成するために炭酸イオン共存下で $\mathrm{Fe}$ (II) イオンの湿式空気酸化反応を行った結果,
$\mathrm{Fe}(\mathrm{II}) \mathrm{Fe}(\mathrm{III})$ 系LDHを経由して $\mathrm{d}=0.74 \mathrm{~nm}$ に回折ピークを 持つ新規な $\mathrm{LDH}$ 類似 $\mathrm{Fe}(\mathrm{III})$ 化合物の単相試料を作製する ことに成功した。

(2) $\mathrm{LDH}$ 類似 $\mathrm{Fe}$ (III) 化合物の生成領域を検討した結果, 反応 温度 $309 \mathrm{~K}$ 以下で $\mathrm{Fe}(\mathrm{II})$ に対する炭酸ナトリウムの比率が $200 \mathrm{~mol} \%$ 以上の領域で, $\mathrm{Fe}(\mathrm{III})$ 系 LDHが生成することが 明らかとなった。

(3) $\mathrm{LDH}$ 類似 $\mathrm{Fe}(\mathrm{III})$ 化合物粒子はハイドロタルサイトと同様 の構造を有する板状単結晶粒子であり, 直径約 $2 \sim 3 \mathrm{~nm}$ の 細孔があることが明らかになった。

(4) LDH類似 Fe(III) 化合物のメスバウアースペクトルを測定 した結果, 結晶中の $\mathrm{Fe}(\mathrm{III})$ イオンを取り巻く酸素イオン や水酸イオンの配置は，一般的な含水酸化鉄を構成して いる $\mathrm{Fe}(\mathrm{III})$ イオンのそれよりも歪んでいることが明らか となった.

(5) $\mathrm{LDH}$ 類似 Fe(III) 化合物は簡単な低温加熱処理によってそ の層状構造以外の構造をほとんぞ崩すことなく比表面積 を増大させることが可能である. LDH 類似 Fe(III) 化合物 は活性が高い物質であることが明らかとなった。

(6) $\mathrm{LDH}$ 類似 $\mathrm{Fe}(\mathrm{III})$ 化合物粉末は相対分圧 $80 \%$ 以上の領域で 急激に水蒸気吸着量が增大することから，メりポア領域 (2〜 50 nm)の細孔を持つことが明らかとなった.

\section{謝辞}

本研究を遂行するにあたり, 岡山大学大学院自然科学研究 科の中西真博士および倉敷芸術科学大学芸術学部の草野圭弘 准教授から貴重なご助言を頂きましたことを心より感謝いた します。

\section{文献}

1) S. Miyata: "Physico-chemical properties of synthetic hydrotalcites in relation to composition", Clays and Clay Minerals, 28(1980) 50-56.

2) S. Miyata: "Properties and adsorption characteristic of hydrotalcites", Gypusum \& Lime, 17(1983)333-339.

3) H. Nakayama, N. Wada, and M. Tsuhako: "Intercalation of amino acids and peptides into $\mathrm{Mg}$-Al layered double hydroxide by reconstruction method", International. Journal of Pharmacy, 269(2004)469-478.

4) R. Allmann: "The crystal structure of pyroaurite", Acta Crystallographica, B24(1968)972-977.

5) K. Hash, S. Kikkawa, and M. Koizumi: "Preparation and properties of pyroaurite-like hydroxyl minelals", Clays and Clay Minerals, 31 (1983)152-154.

6) H.C. Hansen, C.B. Koch, and R.M. Taylor: "Synthesis and characterization of cobalt(II)-iron(III) hydroxide carbonate, a layered double hydroxide belonging to the pyroaurite group", Journal of Solid State Chemistry, 113(1994)46-53.

7) D.L. Bish and A. Livingstone: "The crystal chemistry and 
paragenesis of honessite and hydrohonessite:the sulphate analogues of reevesite", Mineralogical Magazine, 44(1981) 339-343.

8) H. Drissi, Ph. Refait, and J.-M.R. Genin: "The oxidation of $\mathrm{Fe}(\mathrm{OH})_{2}$ in the presence of carbonate ions: structure of carbonate green rust one", Hyperfine Interactions, 90(1994) 395-400.

9) N. Horiishi: "3.2.1 Chemistry of Green Rust G II", Kinousei sankatetsufun to sono ouyo, Yoneda Publishing, (2006) 34.

10) L. Legrand, L. Mazerolles, and A. Chausse: "The oxidation of carbonate green rust into ferric phases: solid-state reaction or transformation via solution", Geochimica et Cosmochimica Acta, 68(2004)3497-3507.

11) T. Shinjo: "Mössbauer effect in antiferromagnetic fine particle",
Journal of Physical Society of Japan, 21 (1966)917-922.

12) E. Murad and U. Schwertmann: "The Mössbauer spectrum of ferrihydrite and its relations to those of other iron oxides", American Mineralogist, 65(1980)1044-1049.

13) Y. Shibasaki, et al.: "Surface conditions and plasticity of the body of $\alpha-\mathrm{Fe}_{2} \mathrm{O}_{3}$ powder", J. Jpn. Soc. Powder Powder Metallurgy, 35(1988)606-609.

14) H. Naono and R.Fujiwara: "Micropore formation due to thermal decomposition of acicular microcrystals of $\alpha \mathrm{FeOOH}$ ", Journal of Colloid and Interface Science, 73(1980)406-415.

15) H. Yoshida: "2. Microporous structure and measuring method", Handbook on Porus Adsorbents, (2005) 20.

16) H. Yoshida: "3. Characterization and adsorption properties of nano sized silica", Handbook on Porus Adsorbents, (2005) 160. 